\title{
Conchavos, conflitos e conluios: a gestão do ano de 2013 da CDHM pelo Deputado e Pastor Marco Feliciano
}

\author{
Edemir Antunes Filho* \\ Ana Keila Mosca Pinezi \\ Sidney Jard da Silva
}

\section{Resumo}

O presente artigo, fundamentando-se em teóricos das Ciências Sociais que estudam a relação entre política e religião, propõe-se a apresentar e analisar os achados de pesquisa realizada sobre a atuação de políticos evangélicos da Frente Parlamentar Evangélica (FPE) no Congresso Nacional Brasileiro. Analisa-se a gestão do ano de 2013 da Comissão de Direitos Humanos e Minorias da Câmara dos Deputados (CDHM), sob direção de Marco Feliciano, deputado e pastor da Igreja Assembleia de Deus, filiado ao Partido Social Cristão (PSC), integrante assíduo da FPE e um dos mais árduos defensores de uma moral conservadora que abarca temas como família, raça, religião, sexualidade e função reprodutiva. O objetivo central da pesquisa é verificar o impacto do conservadorismo, de viés religioso, na agenda da CDHM e os possíveis prejuízos aos direitos humanos de minorias. Para tanto, analisa-se as notas taquigráficas, os requerimentos, os relatórios, os vídeos das sessões e demais documentos da CDHM produzidos em 2013 e disponibilizados no Portal da Câmara dos Deputados.

Palavras-chave: política, religião, Câmara dos Deputados, CDHM, Marco Feliciano.

\section{Conchavos, Conflicts and Stunts: the Management of the Year of 2013 of the CDHM by the Deputy and Pastor Marco Feliciano}

\begin{abstract}
The present article, based on social science theorists who study the relationship between politics and religion, proposes to present and analyze the research findings on the performance of evangelical politicians of the Evangelical Parliamentary Front (FPE) in
\end{abstract}

* Doutor em Ciências da Religião pela UMESP. Email: professoredemir@hotmail.com 
the Brazilian National Congress. The year 2013 management of the Human Rights and Minorities Commission of the Chamber of Deputies (CDHM), under the direction of Marco Feliciano, deputy and pastor of the Assemblies of God Church, affiliated with the Christian Social Party (PSC), a frequent member of the FPE and one of the most ardent advocates of a conservative morality that covers topics such as family, race, religion, sexuality and reproductive function. The central objective of the research is to verify the impact of conservatism, religious bias, on the CDHM agenda and possible harm to the human rights of minorities. In order to do so, we analyze the shorthand notes, the requirements, the reports, the videos of the sessions and other documents of the CDHM produced in 2013 and made available in the Portal of the Chamber of Deputies.

Key-words: politics, religion, Chamber of Deputies, CDHM, Marco Feliciano.

\section{Conchavos, conflictos y colusiones: la gestión del año 2013 de la CDHM por el Diputado y Pastor Marco Feliciano}

\section{Resumen}

El presente artículo, fundamentándose en teóricos de las Ciencias Sociales que estudian la relación entre política y religión, se propone presentar y analizar los hallazgos de investigación realizada sobre la actuación de políticos evangélicos del Frente Parlamentario Evangélico (FPE) en el Congreso Nacional Brasileño. Se analiza la gestión del año 2013 de la Comisión de Derechos Humanos y Minorías de la Cámara de Diputados (CDHM), bajo la dirección de Marco Feliciano, diputado y pastor de la Iglesia Asamblea de Dios, afiliado al Partido Social Cristiano (PSC), integrante asiduo de la FPE y uno de los más arduos defensores de una moral conservadora que abarca temas como familia, raza, religión, sexualidad y función reproductiva. El objetivo central de la investigación es verificar el impacto del conservadurismo, de sesgo religioso, en la agenda de la CDHM y los posibles perjuicios a los derechos humanos de minorías. Para ello, se analizan las notas taquigráficas, los requerimientos, los informes, los videos de las sesiones y demás documentos de la CDHM producidos en 2013 y disponibles en el Portal de la Cámara de Diputados.

Palabras-clave: política, religión, Cámara de Diputados, CDHM, Marco Feliciano.

\section{Introdução}

Este artigo propõe-se a apresentar e a analisar os achados da pesquisa realizada sobre a relação entre política e religião no Brasil, principalmente no que se refere aos evangélicos que marcam presença no Congresso Nacional. Para tanto, é analisada a gestão do ano de 2013 da Comissão de Direitos Humanos e Minorias da Câmara dos Deputados (CDHM) por Marco Feliciano, deputado e pastor da Igreja Assembleia de Deus, filiado ao Partido Social Cristão $\left(\right.$ PSC $^{1}$ - SP), integrante assíduo da FPE e um dos

Sobre o PSC e a moral conservadora ver a pesquisa de Santos (2014) titulada "O PSC e a noção de "Família tradicional" como identidade partidária e religiosa: análise do processo eleitoral de 2014. 
mais árduos defensores de uma moral conservadora (BOBBIO, MATEUCCI, e PASQUINO, 1992). O objetivo central é verificar o impacto deste conservadorismo, de corte religioso, na agenda da CDHM e os possíveis prejuízos aos direitos humanos, em especial às pessoas negras e LGBTs, e fiéis das religiões de matriz africana e espírita. Os objetivos específicos são os seguintes: avaliar o trabalho do Deputado Pastor Marco Feliciano à frente da CDHM; estudar as tensões ocorridas durante a presidência de Marco Feliciano; e analisar quais são os prejuízos que a gestão de Feliciano gerou às minorias.

Feliciano, ao longo de 2013, ficou conhecido pelas declarações polêmicas em programas de televisão brasileiros e nas redes sociais. As maiores controvérsias se deram em torno do seu ponto de vista sobre as populações LGBT e negra, a prática do aborto, as religiões não-cristãs, o comunismo, a maioridade penal, a pobreza, o trabalho e o capitalismo. Esta exposição midiática do Deputado Pastor cooperou para a construção do objeto de pesquisa que culminou com o presente artigo.

Assim sendo, considera-se as produções de cientistas sociais que estudam a relação entre religião e política no Brasil para compreender e analisar, neste artigo, as ações da CDHM durante o período de 2013 que contemplem de algum modo, os intentos conservadores de Marco Feliciano. Por conseguinte, avaliam-se todas as notas taquigráficas e vídeos das reuniões ordinárias e extraordinárias. E, para fins de comparação, analisam-se os relatórios anuais da Comissão disponibilizados no site da Câmara dos Deputados.

Com este procedimento metodológico coletou-se dados cuja análise possibilita explicar como esses atores sociais, Feliciano e seus correligionários, compreendem e experimentam a política, e como ressignificam os objetos e práticas relacionadas ao espaço da CDHM (BORGES, 2005; KUSCHNIR, 2007) abalizados por um conservadorismo religioso. A compreensão deste caso político específico, em situações especiais no interior da Câmara dos Deputados, conduz a comparações e diálogos com a literatura das Ciências Sociais que discute a participação evangélica na política institucional brasileira. Permite, ao mesmo tempo, apreender que a confluência de interesses em torno de uma moral conservadora sustenta e possibilita uma unidade provisória entre parlamentares evangélicos e católicos na Comissão, além de reforçar a mediação que esses deputados e deputadas fazem com os seus eleitores e instituições religiosas que lhes dão aporte. 
A análise dos documentos da CDHM, como assevera Peirano (2004) ao tratar de documentos políticos oficiais como um dos objetivos da Antropologia Política, "tanto revelam quanto põem em ação essas entidades que concebemos abstratamente como nação, Estado, cidadania, democracia” (PEIRANO, 2004, p. 26). Tais documentos, retomando os estudos da Análise de Discurso propostos por Baccega (1998) e Orlandi (2003), são compreendidos aqui como discursos. O discurso não mais diz respeito apenas ao conteúdo de um texto, falado ou escrito. O conteúdo também contribui para a construção de sentido de um determinado texto, mas, além desse elemento, a forma e as informações extraverbais, como as de quem fala, para quem e em qual situação de comunicação, também são elementos que caracterizam a noção de discurso. Enfim, compreende-se que os documentos da CDHM são discursos reais, na sua utilização concreta e única da língua em forma oral ou escrita, decorrentes dos integrantes de um campo da atividade humana. Portanto, o sentido ou a construção do sentido pelo discurso, ou pelo enunciado real, dá-se em razão do contexto e das relações entre os/as participantes do discurso. Este é, também, linguagem em interação que não se desprende do contexto histórico, político e ideológico (CILLA e JARD DA SILVA, 2015).

\section{A participação evangélica na arena pública brasileira}

Nas últimas três décadas a inserção das religiões no espaço público brasileiro intensificou-se. No período, observou-se a desprivatização e publicização da religião (CASANOVA, 1994; MONTERO, 2006) desdobrando-se em diversas formas de representação política e integração em fóruns públicos de discussão. Vários segmentos evangélicos, mais do que anelarem a ocupação da cena política e participarem do jogo eleitoral, adentraram espaços de poder, obtiveram prestígio e influência, protagonizaram ações públicas e participaram de decisões de importância nacional, o que gerou transformações efetivas no cenário político brasileiro. Por estes motivos, Giumbelli (2008) assevera que o fenômeno religioso brasileiro não pode ser mais ignorado no campo da política.

Conforme Burity (2001; 2006), na contemporaneidade as fronteiras demarcatórias dos territórios sociais se deslocaram favorecendo a fluidez e o trânsito entre política e religião. Isso é destacado por Gouveia (2005) como desterritorialização da fé. Já Oro e Mariano (2010) pontuam que religião e política caminham próximas desde o Brasil colonial, mas na atualidade é realmente perceptível que há menos separação e oposição do que aproximação e ininterrupção entre ambas as esferas. Não obstante, os evangélicos que outrora 
se mantinham separados da política por uma percepção dualista e maniqueísta da realidade, agora se lançam aos processos eleitorais e disputas políticopartidárias para moralizar e purificar os espaços públicos (MARIANO, 2005; 2006; 2011). Um exemplo desta tendência evangélica é a criação da $\mathrm{FPE}^{2}$ na $52^{\mathrm{a}}$ legislatura (2003-2006), no dia 18 de setembro de 2003, com o objetivo inicial de reunir parlamentares para realização de cultos e alinhar uma pauta moral. ${ }^{3}$

A mobilização política de grupos evangélicos teve importante implicação no resultado das eleições de 2010 no âmbito federal. Basta rememorar que a FPE, após o período eleitoral, passou de 43 congressistas para 71 deputados federais e 3 senadores na nova legislatura iniciada em 2011. ${ }^{4}$ Estes políticos evangélicos ficaram em evidência logo no início da legislatura pela estridente oposição à proposta do Ministério da Educação e Cultura (MEC) de distribuir um material anti-homofobia em todas as escolas públicas. As declarações públicas dos integrantes da FPE contra as pessoas homossexuais e a "cartilha" da ME foi tão intensa que a Presidente da República, Dilma Vana Rousseff, suspendeu a distribuição do material educativo (CAMPOS, 2005; 2010). Este posicionamento foi interpretado por evangélicos de muitas denominações como uma "vitória de Deus sobre o Diabo", reforçando que as igrejas devem continuar se mobilizando com o propósito de eleger religiosos para os cargos de poder. ${ }^{5}$

Um dos membros desta nova FPE é o deputado e pastor assembleiano Marco Feliciano. Embora estivesse na sua primeira legislatura, já era possível vê-lo discursando eloquentemente na Câmara e noutros espaços em defesa da família tradicional e da moral cristã. Ele se valia de um discurso baseado no modelo ético-normativo (SADEK, 1999), isto é, buscando transferir

2 Conforme: Ata da 193a Sessão, em 18 de setembro de 2003, p. 479.

3 Ver: BRASÍLIA: Câmara dos Deputados, Ata da 193 ${ }^{a}$ Sessão, em 18 de setembro de 2003, p. 406.

4 Conforme dados do Departamento Intersindical de Assessoria Parlamentar (DIAP), de 18 de outubro de 2018, a bancada evangélica eleita em 2018 aumentou na comparação com as eleições de 2014. Foram eleitos ou reeleitos 84 deputados identificados com as demandas, crenças e convicções deste segmento de interesse informal e suprapartidário na Câmara Federal. Em 2014, levantamento do DIAP identificou 75 deputados. Em 2010, a bancada iniciou os trabalhos legislativos com 73 representantes; Ver: https:// www.diap.org.br/index.php/noticias/noticias/28532-eleicoes-2018-bancada-evangelicacresce-na-camara-e-no-senado

5 Esta informação se encontra em dois links do site da Folha de São Paulo/UOL: http:// www1.folha.uol.com.br/cotidiano/917220-bancada-evangelica-diz-que-nao-vota-nadaate-esclarecer-kit-gay.shtml/ ehttp://www1.folha.uol.com.br/poder/90455-em-protestocontra-kit-gay-bancada-evangelica-mira-palocci.shtml; Ver também: http:/BR.noticiais. yahoo.cm/Dilma-suspende-elabora\%c3\%a3o-kit-anti-homobia-escolas-175808443.html 
para o espaço público códigos religiosos próprios do âmbito privado. Aliás, a unidade entre os evangélicos parlamentares, que os movia aos lobbies e às articulações políticas nos bastidores da Câmara, se dava apenas em torno da moralidade privada e de assuntos que dizem respeito aos interesses das igrejas. Freston (1993; 2006) e Pierucci (1996) indicam em suas pesquisas que esta postura já era adotada desde os anos 1980 por alguns políticos evangélicos na Câmara. Perdura, por conseguinte, a tendência de evitar controvérsias políticas na FPE em torno de questões ideológicas e orientações partidárias sobre outros temas como economia, gestão pública etc.

\section{Escolha de Feliciano como presidente da CDHM e movimentação parlamentar}

A contundente participação do Deputado Pastor Marco Feliciano na Câmara e a sua capacidade de reunir fiéis e políticos evangélicos facilitaram com que, no início de 2013, sua legenda, o PSC, o indicasse para a presidência da CDHM. Após a indicação e eleição do pastor político, foram imediatas as reações de grupos que lutam pelos direitos humanos alegando que não só o deputado e seu partido não expunham qualquer histórico de envolvimento com a causa que o qualificasse para o posto, como também o parlamentar era conhecido em espaços midiáticos e nas redes sociais por asseverações discriminatórias em relação a mulheres, a negros/as, a homossexuais e a indivíduos que defendem posicionamentos socialistas/comunistas. ${ }^{6}$

O PSC, partido do deputado-pastor, orientando-se pelo protocolo parlamentar ${ }^{7}$, obteve o direito de fazer a indicação para a CDHM. Por mais

6 Nota de repúdio da CUT: https://www.fup.org.br/foruns/plena-fup/3-plena-fup/itemlist/ user/69-2016-03-11-13-22-14?format=feed\&type=atom\&start=410; Declaração contrária à Feliciano do ex-presidente da CDHM, Olívio Dutra ao site Sul 21: https://www.sul21. com.br/noticias/2013/03/vai-ser-a-comissao-contra-os-direitos-humanos-diz-domingosdutra-sobre-feliciano; CNBB aponta a eleição de Feliciano como retrocesso: http:// noticias.uol.com.br/politica/ultimas-noticias/2013/03/22/cbjp-chama-de-retrocessoter-feliciano-como-presidente-de-comissao-na-camara.htm; Líderes evangélicos lançam manifesto contra Feliciano na CDHM: https://congressoemfoco.uol.com.br/especial/ noticias/o-manifesto-de-lideres-evangelicos-contra-feliciano-na-cdh; Site IGAY coloca-se contrário a Feliciano: https://igay.ig.com.br/2013-03-11/artistas-e-personalidades-criticampresidente-da-comissao-dos-direitos-humanos.html

7 A composição anual da CDHM orienta-se pelo regulamento concernente à representação proporcional dos Partidos e Blocos Parlamentares (Art. 23 do Regimento Interno da Câmara dos Deputados - RICD); na prática, apesar disso, em seguida às designações, as vagas podem ser modificadas mediante as negociações partidárias. A resolução a cerca do número de integrantes que compete a cada uma delas é realizada pela Mesa da Câmara, respeitado o disposto em seu Art. 25, e pode variar anualmente. 
que se façam reflexões, em especial quanto ao porquê de a defesa dos direitos humanos ser colocada pelos grandes partidos, neste caso encabeçada pelo PT, como meio de barganha, há uma forma de ação peculiar no interior da Câmara dos Deputados. Uma vez que os blocos partidários que atuam no Congresso escolhem, anualmente, atuar em Comissões Parlamentares de acordo com os seus interesses, torna-se comum a presença majoritária de um determinado partido ou Frente Parlamentar qualquer numa Comissão. É por este motivo que a Frente Parlamentar Evangélica (FPE), identificada com bandeiras de defesa da família, da moral, dos bons costumes e da censura às práticas e dos direitos da população LGBT, ocupou 17 vagas das 22 que compunham as cadeiras parlamentares na CDHM. Logo, a eleição de Feliciano como presidente da CDHM resulta da sua atuação e influência na FPE, além de ser um pastor evangélico ligado à Assembleia de Deus que havia recebido 211.855 votos nas eleições de 2010 .

A CDHM é um órgão técnico, criado pelo Regimento Interno da Câmara e constituído por deputados/as, com a finalidade de discutir e votar as propostas de leis que são apresentadas à Câmara. Com relação a determinadas proposições ou projetos, essa Comissão se manifesta emitindo opinião técnica sobre o assunto, por meio de pareceres, antes de o assunto ser levado ao Plenário. $\mathrm{Na}$ ação fiscalizadora, a Comissão atua como mecanismo de controle dos programas e projetos executados ou em execução, a cargo do Poder Executivo. Entretanto, como se observará alhures, durante a gestão de Feliciano a laicidade foi suplantada na CDHM pela inserção de alguns assuntos próprios do meio evangélico e o tratamento dado às questões dos direitos humanos e das minorias se respaldava nas crenças religiosas dos membros da Comissão e nos pareceres técnicos que corroboravam estas cosmovisões.

Ao lado da intensa vida religiosa como pastor e preletor, no espaço da Câmara dos Deputados, Feliciano também se apresenta atuante nas sessões plenárias ordinárias e extraordinárias, nas Comissões que participa, nas reuniões da FPE e nos cultos evangélicos que ocorrem nas dependências do Parlamento. Conforme dados disponibilizados no site da Câmara dos Deputados, destacamse no quadro abaixo informações gerais sobre a movimentação parlamentar do Deputado Marco Feliciano no contexto da $54^{\text {a }}$ Legislatura. $^{8}$

8 No quadro abaixo, destacam-se as proposições de autoria de Feliciano, no âmbito da CDHM, que podem ser relacionadas ao seu conservadorismo moral-religioso. 
Quadro 1 - Movimentação Parlamentar de Feliciano

\begin{tabular}{|c|c|c|}
\hline Proposição & $\begin{array}{c}\text { Data de } \\
\text { apresentação }\end{array}$ & Objetivo \\
\hline $\begin{array}{c}\text { REQ-55/2013 } \\
\text { CDHM }\end{array}$ & $18 / 7 / 2013$ & $\begin{array}{l}\text { Requer a realização de Auditoria Operacional do Tribunal } \\
\text { de Contas da União no sentido de avaliar o Programa Brasil } \\
\text { Quilombola coordenado pela Secretaria de Políticas de Pro- } \\
\text { moção da Igualdade Racial-SEPPIR. }\end{array}$ \\
\hline $\begin{array}{l}\text { REQ-6/2013 } \\
\text { CDHM }\end{array}$ & $12 / 3 / 2013$ & $\begin{array}{l}\text { Requer a realização de audiência pública para debater o } \\
\text { desafio da inclusão no mercado de trabalho, assegurando a } \\
\text { igualdade de direitos e oportunidades, sem discriminação de } \\
\text { cor, etnia, procedência ou qualquer outra. }\end{array}$ \\
\hline $\begin{array}{c}\text { REQ-74/2013 } \\
\text { CDHM }\end{array}$ & $17 / 9 / 2013$ & $\begin{array}{l}\text { Requer que seja aprovado pela Comissão de Direitos Huma- } \\
\text { nos e Minorias apresentação de Projeto de Decreto Legis- } \\
\text { lativo que convoca plebiscito para consulta popular sobre a } \\
\text { maioridade penal. }\end{array}$ \\
\hline $\begin{array}{l}\text { REQ- } \\
7989 / 2013\end{array}$ & $14 / 6 / 2013$ & $\begin{array}{l}\text { Requer a revisão do despacho dado ao PL } 478 / 2007 \text { - Estatu- } \\
\text { to do Nascituro, a fim de que o mesmo tramite pela Comissão } \\
\text { de Direitos Humanos e Minorias. }\end{array}$ \\
\hline $\begin{array}{c}\text { REQ- } \\
8007 / 2013\end{array}$ & $18 / 6 / 2013$ & $\begin{array}{l}\text { Requer a revisão do despacho dado ao PL } 2845 / 2003 \text { - Esta- } \\
\text { belece normas para a organização e a manutenção de políticas } \\
\text { públicas específicas de prevenção e enfrentamento ao tráfico } \\
\text { de seres humanos, especialmente mulheres e crianças, institui } \\
\text { o Sistema Nacional de Prevenção e Enfrentamento ao Tráfico } \\
\text { de Seres Humanos e dispõe sobre a regulamentação de seus } \\
\text { aspectos civis e penais. }\end{array}$ \\
\hline $\begin{array}{c}\text { REQ-89/2013 } \\
\text { CDHM }\end{array}$ & $29 / 10 / 2013$ & $\begin{array}{l}\text { Ementa: Requer a realização de Reunião de Audiência Pública } \\
\text { para discutir o Aborto. }\end{array}$ \\
\hline $\begin{array}{l}\text { REQ-94/2013 } \\
\text { CDHM }\end{array}$ & $13 / 11 / 2013$ & $\begin{array}{l}\text { Requer a realização de Audiência Pública para debater os } \\
\text { motivos que impedem o Poder Público a implementar o en- } \\
\text { sino da história da África e dos Afro-brasileiros, em descum- } \\
\text { primento ao que determina o art. 26-A, da Lei 9.394/1996. }\end{array}$ \\
\hline $\begin{array}{c}\text { RIC- } \\
3918 / 2013\end{array}$ & $17 / 12 / 2013$ & $\begin{array}{l}\text { Solicita informações à Sra. Ministra de Estado da Secretaria } \\
\text { de Direitos Humanos da Presidência da República sobre os } \\
\text { repasses orçamentários e financeiros para entidades ligadas } \\
\text { ao movimento LGBT. }\end{array}$ \\
\hline $\begin{array}{c}\text { REQ- } \\
9198 / 2013\end{array}$ & $10 / 12 / 2013$ & $\begin{array}{l}\text { Requer revisão do despacho aposto ao Projeto de Lei n. } \\
4.703 / 1998 \text {, de modo a distribuí-lo à Comissão de Direitos } \\
\text { Humanos e Minorias, preservando-se as distribuições para } \\
\text { as demais comissões. }\end{array}$ \\
\hline
\end{tabular}

Fonte: http://www.camara.leg.br/buscaProposicoesWeb/pesquisaSimplificada. Acesso em: 20 de fevereiro de 2017. [Elaborado pelos autores.] 
Os requerimentos, as propostas, as diligências e demais ações da CDHM são viabilizadas pela atuação direta do seu gestor. Portanto, o posicionamento deste interfere na agenda da Comissão sinalizando aos seus pares a positividade dos temas (SANTOS e ALMEIDA, 2005; 2011a; 2011b;SANTOS e CANELLO, 2016). Como gestor de um órgão interno e pelo contato próximo com o presidente da Câmara dos Deputados, o Deputado Henrique Eduardo Alves (PMDB - RN), ${ }^{9}$ Marco Feliciano tem as informações mais precisas sobre a abertura do parlamento para tratar de certos assuntos. Valendo-se de sua posição, Feliciano pratica uma movimentação parlamentar direcionada à manutenção do seu cargo e em diálogo com o seu eleitorado.

Embora não haja tempo para apresentar todas as proposições da CDHM, cabe salientar que os parlamentares evangélicos apresentaram 146 proposições (88\%), e os católicos 20 proposições (12\%). Estas 20 últimas foram propostas por uma deputada e três deputados aliados de Feliciano, a saber, Keiko Ota (PSB-SP), Jair Bolsonaro (PP-RJ), Severino Ninho (PSBPE) e Simplício Araújo (PPS-MA). A abordagem e tratamento despendidos aos assuntos na Comissão são evidentemente norteados pela perspectiva "conservadora" acordada pela FPE. Evidências de que este ponto de vista seria assinalado na Comissão em 2013 são notados no discurso do presidente da FPE, o deputado João Campos (PSDB-GO). Por ocasião da eleição de Feliciano como presidente da CDHM, Campos discursa em sessão da Câmara:

...permita-me de forma breve e sucinta trazer aqui uma posição da Frente Parlamentar Evangélica do Congresso Nacional, que tenho a honra de presidir, em relação à Comissão de Direitos Humanos desta Casa e ao processo de eleição que ali se deu. A posição da Frente Parlamentar Evangélica, de forma unânime, Sr. Presidente, é - em primeiro lugar - defender a livre manifestação do pensamento, um dos pilares da democracia. E aquilo que se refere ao Parlamentar é uma prerrogativa do Parlamentar. Que todos discordem, se for a hipótese, do Presidente Deputado Pastor Marco Feliciano, mas que não percamos de vista que o direito de opinião e da livre manifestação é um dos pilares da democracia.... nós entendemos, a Frente Parlamentar Evangélica, que a eleição do Deputado Marco Feliciano, mesmo havendo sobre ela divergência, que é própria do Parlamento, é um ganho para esta Casa e um ganho para a

O Deputado Henrique Eduardo Alves foi presidente da Câmara dos Deputados entre 4 de fevereiro de 2013 a 1 de fevereiro de 2015. Em 2013, também atuava como líder de um bloco partidário formado por PMDB, PT, DEM, PR, PDT, PV, PPS, PHS, PTdoB, PTC, PRTB e PSC. Este último é o partido do Deputado Marco Feliciano. 
sociedade brasileira, porque a Comissão de Direitos Humanos e Minorias, a partir da eleição de V.Exa., tem a oportunidade de discutir direitos humanos em uma perspectiva mundial, sem estar subordinada a ideologias, a partidos ou a guetos ideológicos. A Comissão vai discutir agora direitos humanos em todas as suas vertentes. Isso é um ganho para esta Casa e para o Parlamento. ${ }^{10}$

O discurso de João Campos demonstra que há uma orientação para os integrantes da FPE defenderem em todas as instâncias as pautas morais. Embora o quadro acima saliente que apenas nove requerimentos tratem dos assuntos mais polêmicos e que mais inquietam os seus apoiadores evangélicos, Feliciano observa esta orientação moral na presidência da CDHM, incluindo temas que lhe são caros, bem como discussões de cunho religioso, que seriam mais apropriados para eventos eclesiásticos. Os seus pares evangélicos e os correligionários católicos alinhados permitem com que os temas e encaminhamentos sejam feitos de modo a transparecer sobriedade, acordo e harmonia. ${ }^{11}$ Observar-se aqui o corporativismo e fisiologismo praticados pela FPE na CDHM com a anuência combinada com as lideranças partidárias no parlamento. De fato, as tensões, os alardes e as polêmicas desta gestão ocorrem em menor grau nas sessões da Câmara dos Deputados e, intensamente, no ambiente externo e nos meios de comunicação.

\section{O Deputado Pastor Marco Feliciano à frente da CDHM}

Um número importante de parlamentares ligados à FPE atuou na CDHM em 2013 durante a presidência de Feliciano. Avaliando as notas taquigráficas de todas as reuniões, apesar da estrutura organizativa da Comissão, são a deputada e os deputados pertencentes a igrejas evangélicas aqueles que efetivamente atuam. E, dentre os políticos que são fiéis católicos, destacam-se as atuações da Deputada Keiko Ota e do Deputado Jair Bolsonaro. ${ }^{12}$ Abaixo segue a lista completa dos integrantes desta:

\footnotetext{
10 CAMPOS, J. Discursos e notas taquigráficas. Sessão 053.3.54O em 03 abr. 2013. Disponível em: http://www.camara.gov.br/internet/sitaqweb/DiscursosDeputado.asp.

11 Sobre esta "cultura" religiosa de viés conservador presente no parlamento brasileiro cabe a revisão da pesquisa de Baptista (2009) sobre os pentecostais e neopentecostais na política brasileira.

12 Conforme dados disponibilizados no site da FPE, o Deputado Jair Bolsonaro integra esta Frente como seu convidado de honra. Em 2018, em uma campanha fortemente apoiada por lideranças evangélicas, e sob o lema "Brasil acima de tudo, Deus acima de todos", Jair Messias Bolsonaro foi eleito o $38^{\circ}$ Presidente da República.
} 
Conchavos, conflitos e conluios: a gestão do ano de 2013183

da CDHM pelo Deputado e Pastor Marco Feliciano

Quadro 2 - Lista de integrantes da CDHM

\begin{tabular}{|c|c|c|c|}
\hline Função & Deputado/a & $\begin{array}{l}\text { Partido } \\
\text { político }\end{array}$ & Igreja \\
\hline Presidente & Pastor Marco Feliciano & PSC/SP & Assembleia de Deus \\
\hline $\begin{array}{c}1^{\text {a }} \text { Vice-presi- } \\
\text { dente }\end{array}$ & Antônia Lúcia & $\mathrm{PSC} / \mathrm{AC}$ & Assembleia de Deus \\
\hline $2^{a}$ Vice-presidente & Liliam Sá & $\mathrm{PROS} / \mathrm{RJ}$ & Igreja Presbiteriana \\
\hline $3^{\circ}$ Vice-presidente & Anderson Ferreira & $\mathrm{PR} / \mathrm{PE}$ & Assembleia de Deus \\
\hline Titular & Pedro Guerra & $\mathrm{PSD} / \mathrm{PR}$ & Igreja Católica Apostólica Romana \\
\hline Titular & Keiko Ota & $\mathrm{PSB} / \mathrm{SP}$ & Igreja Católica Apostólica Romana \\
\hline Titular & Pastor Eurico & $\mathrm{PSB} / \mathrm{PE}$ & Assembleia de Deus \\
\hline Titular & Enio Bacci & $\mathrm{PDT} / \mathrm{RS}$ & Igreja Católica Apostólica Romana \\
\hline Titular & Henrique Afonso & $\mathrm{PV} / \mathrm{AC}$ & Igreja Presbiteriana \\
\hline Titular & Simplício Araújo & $\mathrm{SD} / \mathrm{MA}$ & Igreja Católica Apostólica Romana \\
\hline Titular & Otoniel Lima & $\mathrm{PRB} / \mathrm{SP}$ & Igreja Universal do Reino de Deus \\
\hline Titular & Dr. Carlos Alberto & $\mathrm{PMN} / \mathrm{RJ}$ & Igreja Católica Apostólica Romana \\
\hline Suplente & João Campos & $\mathrm{PSDB} / \mathrm{GO}$ & Assembleia de Deus \\
\hline Suplente & Walter Tosta & $\mathrm{PSD} / \mathrm{MG}$ & Igreja Batista \\
\hline Suplente & Jair Bolsonaro & $\mathrm{PP} / \mathrm{RJ}$ & Igreja Católica Apostólica Romana \\
\hline Suplente & Severino Ninho & $\mathrm{PSB} / \mathrm{PE}$ & Igreja Católica Apostólica Romana \\
\hline Suplente & Marcos Rogério & $\mathrm{PDT} / \mathrm{RO}$ & Assembleia de Deus \\
\hline Suplente & Arnaldo Jordy & $\mathrm{PPS} / \mathrm{PA}$ & Igreja Católica Apostólica Romana \\
\hline Suplente & Roberto de Lucena & $\mathrm{PV} / \mathrm{SP}$ & Igreja O Brasil para Cristo \\
\hline Suplente & Dr. Grilo & $\mathrm{SD} / \mathrm{MG}$ & Igreja Internacional da Graça \\
\hline Suplente & Costa Ferreira & $\mathrm{PSC} / \mathrm{MA}$ & Assembleia de Deus \\
\hline Suplente & Hidekazu Takayama & $\mathrm{PSC} / \mathrm{PR}$ & Assembleia de Deus \\
\hline Suplente & Zequinha Marinho & $\mathrm{PSC} / \mathrm{PA}$ & Assembleia de Deus \\
\hline Suplente & Lourival Mendes & PTdoB/MA & Igreja Batista \\
\hline
\end{tabular}

Fonte: http://www2.camara.leg.br/atividade-legislativa/comissoes/comissoes-permanentes/ cdhm/documentos/relatorios-de-atividades. Acesso em 13 de janeiro de 2017.

[Elaborado pelos autores] 
Feliciano contou com 2/3 de evangélicos na Comissão, ou seja, nove parlamentares da Assembleia de Deus, dois da Igreja Presbiteriana, dois da Igreja Batista e um representante da Igreja Universal do Reino de Deus, da Igreja O Brasil para Cristo e da Igreja Internacional da Graça de Deus. A presidência do Deputado Pastor Marco Feliciano se deu entre 07/03/2013 a 26/02/2014. Avaliando as pessoas que integraram a CDHM, além de Feliciano, destaca-se a presença majoritária de parlamentares evangélicos participantes da FPE, como Henrique Afonso (PV-AC), João Campos (PSDB-GO), Lilian Sá (PROS-RJ) e Pastor Eurico (PSB-PE). Esta atuação evangélica se evidencia em alguns momentos nas atividades da Comissão ao inserirem conteúdos próprios de uma moral cristã conservadora (Mariano, 2016). Quando se averigua a página de Marco Feliciano no site da Câmara dos Deputados é possível notar que todas as atividades da Comissão, como é o caso dos requerimentos $(\mathrm{REQ})^{13}$, estão relacionadas ao seu mandato, mas os pormenores destas somente são aprofundados ao ver os vídeos das sessões e/ou ler as notas taquigráficas das mesmas.

Neste sentido, João Campos, publicamente conhecido por ser favorável a redução da maioridade penal, solicitou e contemplou a aprovação do REQ 41/2013 em 28 de maio com o seguinte teor: "requer que seja promovido pela Comissão de Direitos Humanos e Minorias, Seminário para debater a Redução da Maioridade Penal, em conjunto com a CSPCCO e CCJC". Outro pedido de parlamentar evangélico que logrou êxito é o do deputado Marcos Rogério (PDT/RO), defensor de uma maior flexibilização na redução da maioridade penal. Sua rogativa, sob o registro de REQ 42/2013 CDHM, ficou assim: "à Comissão de Direitos Humanos e Minorias - CDHM - reunião de Audiência Pública para debater a alteração da Maioridade Penal".

Nas sessões que culminaram com o REQ 41/2013 e REQ 42/2013 ficaram nítidos os posicionamentos de parlamentares pró-redução da maioridade penal e, como é comum em reuniões na Câmara, o uso enfático do tom de indignação e de exemplos dramáticos esteve presente na maioria dos discursos dos deputados (AVRITZER, 2009). Este recurso dialógico também marcou o seminário de discussão sobre a redução da maioridade penal ocorrido no mês de agosto de 2013. Para tanto, foram convidados como depoentes a mãe e o pai de um jovem assassinado por um menor de idade, um pastor da Igreja O Brasil Para Cristo, a secretária Nacional

13 Ver: http://www.camara.leg.br/buscaProposicoesWeb/pesquisaSimplificada 
de Promoção dos Direitos da Criança e do Adolescente, da Secretaria de Direitos Humanos da Presidência da República, e a promotora de Justiça e Coordenadora do Centro de Apoio Operacional da Infância e Juventude, do Ministério Público do Pará.

Neste seminário, um dos discursos foi feito pelo deputado Roberto Lucena. Por ser um evangélico próximo de Marco Feliciano, Lucena se vale de argumentos religiosos, semelhantes ao do presidente da CDHM, carregados de dramaticidade e indignação construídos em torno da ideia de que todas as pesquisas da realidade brasileira mostram um grande número da população como favorável à redução da maioridade penal. Em sequência, Feliciano, passa a discursar. Segue abaixo um trecho desta fala selecionada das Notas Taquigráficas de 27 de agosto de 2013:

Vivemos num mundo louco, num mundo que está de pernas para o ar: o certo passou a ser o errado e o errado passou a ser o certo. Quando criança, na escola, na minha época, nós tínhamos um período em que parávamos para fazer uma oração, o Pai-Nosso. Aquilo mexia com a gente, porque falava do sagrado, e todas as crianças da minha época acreditavam que havia algo sagrado. Quando o ser humano sabe ou acredita que existe algo além daquilo que a visão humana pode alcançar, isso dá a ele um pouco mais de esperança e respeito pelo próximo e por si mesmo. ${ }^{14}$

Outro discurso incisivo na ocasião foi proferido pelo então Deputado Jair Bolsonaro (PP/RJ). Este, embora seja fiel da Igreja Católica, recebeu batismo pela Igreja Assembleia de Deus, frequentou a Igreja Batista e integra a Frente Parlamentar Evangélica na Câmara dos Deputados. Bolsonaro já havia declarado publicamente sua amizade com Feliciano, e este motivo cooperou para a sua participação neste seminário que versava sobre a redução da maioridade penal. O seu posicionamento sobre o assunto pode ser percebido nesta seleção do seu discurso:

[...] hoje, tem esta bagunça: direitos humanos para vagabundo é o que não falta neste País. [...] com 15 anos de idade, eu estava na Praça Nossa Senhora da Guia, em Eldorado Paulista, quando passou um caminhão, vindo do interior. Dentro, estava o ex-Capitão Lamarca, com um bando de marginais, meteu

14 Esta e outras informações sobre as ocorrências na CDHM podem ser acessadas no espaço oficial da CDHM no site da Câmara, no item "Notas Taquigráficas": http://www2.camara. leg.br/atividade-legislativa/comissoes/comissoes-permanentes/cdhm/documentos/notastaquigraficas?b_start:int $=0$ 
fogo para tudo quanto é lado, seis soldados foram feridos e uma senhora levou um tiro na perna. Ontem, por coincidência, pela primeira vez na história, a Câmara Municipal teve coragem de fazer sessão solene cumprimentando, saudando o heroísmo desses soldados que enfrentaram o grupo de Lamarca. Detalhe: sabe quem era o comandante da Vanguarda Popular Revolucionária? Dilma Rousseff. [...] O nosso objetivo - há praticamente consenso aqui - é tirar uma posição desta Comissão de Direitos Humanos e Minorias, que é diferente daquela de anos anteriores, que defendia gay, kit gay, tudo quanto é sacanagem para a sociedade. Essa bagunça acabou com o general Feliciano e o capitão Bolsonaro, o assessor, e mais alguns soldados, como o Deputado Roberto de Lucena. ${ }^{15}$

Nenhum dos deputados presentes no seminário posicionou-se de forma contrária à redução da maioridade penal. O contraponto discreto se mostrou nos discursos técnicos sobre o assunto, e só não foi abafado pela eloquência dos parlamentares porque esta sessão e as outras duas reuniões que se realizaram sobre o tema foram registradas nos vídeos e notas taquigráficas. Conquanto não seja possível afirmar categoricamente, ao observar o desenvolvimento do Seminário pareceu que os parlamentares presentes estavam com os seus discursos alinhados em torno da redução da maioridade penal.

Retomando algumas solicitações de parlamentares na Comissão, seguindo a perspectiva de uma moral cristã, o deputado Henrique Afonso LEGENDA - Acre, alinhado aos objetivos de Feliciano, fez o seguinte requerimento acolhido pela presidência e demais membros: "a realização de Audiência Pública para debater a violação dos direitos humanos do nascituro" (REQ 45/2013 CDHM). E o mesmo Afonso, parlamentar envolvido em diversas discussões a respeito da população indígena e comunidades rurais e ao mesmo tempo sensível às temáticas de outras comissões permanentes como a Comissão de Agricultura, Pecuária, Abastecimento e Desenvolvimento Rural (CAPADR) e a Comissão de Integração Nacional, Desenvolvimento Regional e da Amazônia (CINDRA), sugere a "Avaliação das Políticas Indigenistas sobre Demarcação e Mineração em Terras concretizando-se na REQ 60/2013 CDHM"

Outras audiências públicas da Comissão geraram muitas críticas de grupos militantes dos Direitos Humanos e Minorias. Uma delas ocorreu no

15 Cf.: Notas taquigráficas de 27 de agosto de 2013: http://www2.camara.leg.br/atividadelegislativa/comissoes/comissoes-permanentes/cdhm/documentos/notas-taquigraficas 
dia 06 de junho de 2013, com o registro de Dia do Perdão. Na ocasião, o vice-presidente da FEB (Federação Espírita Brasileira), Geraldo Campetti Sobrinho, em seu discurso abordou vários temas, como o valor da oração. Outros convidados enfatizaram o poder salugênico da prática do perdão. Outra audiência polêmica foi sobre a iniciativa privada e as políticas de valorização e proteção a família, especialmente ao modelo familiar tradicional. Destacaram-se ainda as reuniões sobre a condição do Programa Brasil Quilombola, Saúde Indígena, Cultura Cigana, Sistema educativo para menores infratores; a audiência pública que discutiu o "problema da erotização das nossas crianças através de imagens, de músicas nos meios de comunicações, cartilhas educativas e demais exposições"- REQ 50/2013, do Dep. Pastor Eurico; o Dia Nacional do Capelão Evangélico Civil e Militar em 11 de dezembro de 2013 - REQ formalizado a partir do pedido da Deputada Liliam Sá (PROS-RJ); e a audiência para discutir o Aborto (REQ 89/2013 CDHM - do Marco Feliciano) que contou com a presença do Dep. João Campos, autor do requerimento da CPI do Aborto, Hermes Rodrigues Nery, Coordenador da Comissão Diocesana em Defesa da Vida e Movimento Legislação e Vida da Diocese de Taubaté, Thereza de Lamare Franco Neto, Diretora Substituta do Departamento de Ações Programáticas Estratégicas da Secretaria de Atenção à Saúde do Ministério da Saúde.

Para completar os relatos das atividades da CDHM, cabe pontuar algumas audiências que geraram muitas controvérsias e repercussões nacionais e internacionais. A primeira se deu a partir da retomada do PDC 234/2011, conhecido como a cura gay, que suspende a resolução do Conselho Federal de Psicologia que proíbe tratamento para homossexualidade. A solicitação feita pelo deputado João Campos - PSDB foi aprovada na Comissão; a segunda respaldada na PL 1411/2011, de autoria do deputado Washington Reis (PMDB/RJ), também aceita na CDHM, rege que "Descaracteriza crime a recusa, em templos religiosos, de aceitar ou efetuar cerimônias ou pessoas em desacordo com suas crenças e liturgias"; o PDC 232/2011 que é reafirmado na gestão de Feliciano e "dispõe sobre a convocação de plebiscito para decidir sobre a união civil de pessoas do mesmo sexo; respondendo a seguinte questão: "Você é a favor ou contra a união civil de pessoas do mesmo sexo?".

Ainda sobre a temática LGBT, cabe ressaltar que todas as vezes que a Comissão lidou com o assunto foi para rechaçar as reivindicações destes grupos, reafirmar os relacionamentos heterossexuais, bem como arquivar requerimentos que favoreciam de alguma forma as pessoas homoafetivas. Um 
exemplo é a solicitação do parlamentar Maurício Rands do PT que "acresce um parágrafo ao art. 16 da Lei no 8.213, de 24 de julho de 1991, e acresce uma alínea ao inciso I do art. 217 da Lei $n^{\circ}$ 8.112, de 11 de novembro de 1990, para incluir na situação jurídica de dependente, para fins previdenciários, o companheiro homossexual do segurado e a companheira homossexual da segurada do INSS e o companheiro homossexual do servidor e a companheira homossexual da servidora pública civil da União." Esta proposta foi rejeitada e arquivada pela presidência do Deputado Feliciano.

Duas propostas importantes que partiram da CDHM obtiveram êxito na plenária da Câmara dos Deputados, a saber, a "PL 6738/2013 - do Poder Executivo - que reserva aos negros vinte por cento das vagas oferecidas nos concursos públicos para provimento de cargos efetivos e empregos públicos no âmbito da administração pública federal, das autarquias, das fundações públicas, das empresas públicas e das sociedades de economia mista controladas pela União"; e a outra é a "PL 6418/2005 - do Senado Federal - Paulo Paim - (PLS 309/2004) - que "define os crimes resultantes de discriminação e preconceito de raça, cor, etnia, religião ou origem, incluindo o crime de discriminação no mercado de trabalho, injúria resultante de preconceito, apologia ao racismo, atentado contra a identidade étnica, religiosa ou regional e associação criminosa, tornando-os crimes inafiançáveis e imprescritíveis".

A forma como é conduzida as atividades da CDHM, regida por uma pauta "evangélica”, demonstra que há uma opção explícita em comunicar-se com os eleitores das diversas igrejas representadas e transformar o espaço público da Câmara em extensão do ambiente privado da religião (COSTA 2013; 2016; DUARTE 2012; 2013; PINEZI, 2005). Ao mesmo tempo, os políticos religiosos, seguindo as liturgias do parlamento (RIVIĖRE, 1989), reforçam que seus posicionamentos se dão como parte do pluralismo da sociedade e em respeito à laicidade do Estado e as leis brasileiras que não pode privilegiar grupos em detrimento de outros. Com este pragmatismo conveniente, alicerçado em valores de liberdade, respeito, justiça e legitimidade, defendem que é um dever sociopolítico aceitar e conviver com posições diferentes e, muitas vezes, acolher decisões majoritárias que se constroem democraticamente (ALMEIDA, 2017b; BALANDIER, 1982; BARRERA RIVERA, 2006; FONSECA, 2011; MACHADO, 2003; MIRANDA, 1999; MIRANDA, 2010; NOVAES, 2002; ROTONDANO, 2013). 


\section{Tensões durante a presidência de Feliciano}

As tensões internas e externas marcaram a atuação do deputado pastor Marco Feliciano como presidente da CDHM em 2013. Entidades diversas que refletem e defendem os direitos humanos ao lado de ativistas, movimentos sociais e comunidades religiosas, inclusive evangélicas, manifestaram-se contrárias à presidência de Feliciano. $\mathrm{O}$ argumento uníssono dos opositores do pastor era que Feliciano trazia em seu histórico ações misóginas, homofóbicas, racistas, xenofóbicas e preconceituosas com religiões não-cristãs que afrontavam diretamente os direitos humanos e das minorias. Em decorrência disso, a Frente Parlamentar Evangélica, que desde o início da $53^{a}$ Legislatura se envolvia em discussões polêmicas, durante esta gestão da CDHM ficou em maior evidência no Congresso Nacional e nos meios de comunicação.

Se de um lado Feliciano e o grupo de parlamentares que o apoiavam na CDHM alcançou grande visibilidade, de outro, esses parlamentares aproveitavam-se da repercussão do que ocorria na Comissão para fortalecer os vínculos com seus eleitores nas agremiações religiosas e em outros espaços que frequentavam, bem como aceitavam convites para participar de programas de TV, Rádio e Internet com o propósito de debaterem os temas que defendiam para cooptarem votantes. No caso específico de Marco Feliciano, a estratégia foi-lhe favorável, pois na eleição seguinte os votos recebidos foram o dobro se comparados ao seu primeiro mandato como parlamentar.

A pertença religiosa da maioria que integrava a CDHM era a da Igreja Assembleia de Deus. Este fato permitiu com que todos os pastores membros das Assembleias de Deus do Brasil, em reunião conciliar, oferecessem total apoio aos seus representantes na Câmara dos Deputados. Inclusive o do pastor assembleiano Silas Malafaia que, em seu programa de TV "Vitória em Cristo, transmitido na Rede Bandeirantes de Televisão e no Sistema Brasileiro de Televisão, repercutia o trabalho de Feliciano e pressionava o partido político do deputado, o PSC, a se manter firme com as bandeiras de luta em prol da família tradicional e de resistência aos grupos pró-aborto e LGBT.

À medida que a carreira política de Feliciano se desenvolvia, seus posicionamentos vão se tornando conhecidos na Câmara, especialmente entre os contrários à homossexualidade, à dissolução da família tradicional, aos vícios em drogas lícitas e ilícitas, à transformação das condutas da mulher na sociedade brasileira, ao aborto, e à manutenção da maioridade penal em 18 anos. ${ }^{16}$ Tais posições se evidenciaram no exercício do mandato e, possivelmente

16 Em meio às polêmicas evangélicas no Congresso Nacional, Souza (2013) desenvolve um artigo sobre o uso político do sexo por parte de evangélicos. 
pela exposição midiática, acentuaram-se e mobilizaram pessoas, religiosas ou não, que partilhavam os mesmos pontos-de-vista concernentes aos temas que defendia (MIGUEL, BIROLLI e MARIANO, 2017; SYLVESTRE, 2006; TADVALD, 2010).

Como parte da exasperação das controvérsias em torno de Feliciano, uma assertiva feita pelo deputado pastor em 31 de março de 2011, afrontando os povos da África, é retomada por grupos e indivíduos contrários ao novo presidente da CDHM no início de seu mandato. Eles relembram que o deputado, através do Twitter, fez uma postagem com a seguinte afirmação: "Africanos descendem de ancestral amaldiçoado por Noé. Isso é fato." A repercussão desta frase foi imediata e provocou indignações dos movimentos de combate ao racismo e de indivíduos sensíveis à luta do povo negro contra a discriminação, estigmatização e outras formas de violência que sofrem diariamente.

Esta perspectiva teológica a respeito da África fora questionada em uma entrevista que Feliciano concedeu à Revista Época. Ao responder a pergunta, ele se valeu de um texto bíblico do Antigo Testamento para justificar a maldição, pontuando que mulheres e homens africanos têm sofrido ao longo da história com guerras, assassinatos, conflitos civis, doenças graves e pobreza porque descendem de um neto de Noé amaldiçoado por Deus. O problema se agrava, na visão do parlamentar, em razão das variadas religiosidades praticadas na África que divergem do cristianismo.

Possivelmente como resquício da política de branqueamento brasileira (OLIVEIRA, 2008) e da imposição do cristianismo desde o período colonial (BOSI, 1992), além de uma leitura racista da história africana antiga e recente, Feliciano insere na discussão o tema da superioridade cristã em relação às outras religiões. Estas últimas por terem diferentes cosmovisões e práticas cooperam com os problemas sociais supramencionados. A única solução para que as pessoas negras contemplem alguma melhora, na perspectiva do deputado, é converterem-se ao cristianismo. ${ }^{17}$ Evidencia-se com isso que a CDHM de 2013 tornou-se a porta-voz de um cristianismo que não só ignora as religiões de outras matrizes e correntes, como também as desqualifica. Assim, a laicidade do Estado foi completamente descartada e um órgão do Estado representou a perspectiva de apenas uma vertente religiosa da sociedade brasileira, regulando sobre questões de direitos humanos e das minorias à luz de certos "valores cristãos".

17 Sobre os conflitos entre igrejas evangélicas e religiões afro-brasileiras ver: Marés, 2007; e Silva, 2007. 
Diante destas atribuições, o nome de Feliciano, além de ser colocado sob suspeição por integrantes do movimento negro, é duramente questionado pelos movimentos sociais que lutam pela liberdade religiosa por duas razões principais. ${ }^{18}$ A primeira razão para esta desconfiança se firma justamente na declaração do deputado, fundamentada no argumento já explicitado de que a população africana é amaldiçoada por Deus. E a segunda razão está respaldada na assertiva do parlamentar de que o único modo de se ver livre da imprecação divina é aceitar a Jesus Cristo como Senhor e Salvador e filiarse a alguma entidade do cristianismo, especialmente as igrejas evangélicas. Ser cristão/ã evangélico/a, por conseguinte, é o meio para expurgar o mal herdado pela via racial. Nesta perspectiva, Feliciano descarta que a África durante muito tempo fora alvo da manipulação e abusos de "países evangélicos", como é o caso da Inglaterra e EUA, interessados nas riquezas naturais, na escravização e na exploração de "trabalhadores/as", bem como na cristianização da população africana.

É interessante que a dissonância com relação ao discurso da superioridade cristã em relação às outras religiões presentes no Brasil, no interior da CDHM, praticamente inexistiu em 2013. Talvez um aspecto que tenha conferido respaldo a este posicionamento seja o fato de que, conforme os dados do Instituto Brasileiro de Geografia e Estatística, em 2013 mais de $85 \%$ da população brasileira se autodenominava cristã. ${ }^{19}$ Entretanto, ao considerar os 22 membros da Comissão, segundo informações disponibilizadas pelos próprios parlamentares no site da Câmara dos Deputados, 17 eram evangélicos pentecostais e os demais católicos.Com exceção dos protocolos políticos e do modo de tratamento entre os parlamentares, marcados por uma linguagem peculiar em todas reuniões oficiais da Câmara, os discursos proferidos na Comissão estavam carregados

18 Além das reações contrárias a Feliciano advindas da CUT, CNBB, Evangélicos destacadas algures, destacam-se também os manifestos do Conselho Nacional de Promoção da Igualdade Racial (CNPIR) (https://odarainstituto.wordpress.com/page/4/?archives-list=1 ;), da Rede Feminista de Saúde (https://www.viomundo.com.br/politica/rede-feministacontra-marco-feliciano-para-presidir-cdhm.html); das Blogueiras Feministas: https:// blogueirasfeministas.com/2013/03/page/3; do Movimento Negro Unificado (http://www. ceert.org.br/noticias/direitos-humanos/3413/contra-feliciano-cdhm-alternativa-reunepoliticos-e-ativistas-em-sp); do Movimento "Fora Feliciano" do Facebook: https://www. facebook.com/events/563738633650470; da Associação Brasileira de LGBT: https:// www.em.com.br/app/noticia/politica/2013/04/14/interna_politica,371233/polemicacom-feliciano-da-maior-visibilidade-a-questoes-relativas-aos-direitos-humanos.shtml;

19 Disponível em: http://www.ibge.gov.br/home/. Acesso em 24 de maio de 2017. 
de expressões comuns aos espaços dos cultos evangélicos e das missas católicas.

As controvérsias em torno da gestão de Feliciano não se circunscreveram às questões racial e religiosa, mas envolveram tensões em relação à população LGBT. ${ }^{20}$ Desde o princípio, o pastor deputado se mostrou contrário a qualquer tipo de proposta com vistas aos direitos do público homossexual. Havia, até então, uma resolução do Conselho Federal de Psicologia (CFP) que estabelecia normas para os/as psicólogos/as sobre o modo de lidar com o tema da orientação sexual. De modo resumido, os/as profissionais da área não tinham autorização para propor um tratamento ou cura da homossexualidade pela via psicológica, pois deixou de ser considerada uma doença ou um desvio psicológico. Sabedor deste impedimento, Feliciano propõe a votação de um projeto, chamado de "Cura Gay," para revogar a resolução do CFP.

Com a defesa de que as pessoas gays poderiam ser curadas com tratamento psicológico e com o apoio de orações, Marco Feliciano passa a ser chamado a falar sobre o tema em programas televisivos populares e, com isso, as tensões com os movimentos LGBTs aumentam demasiadamente. Isso repercute até mesmo nas reuniões da CDHM que deixam de ser abertas à população e, por ordem do presidente Feliciano, passa a ocorrer de portas fechadas. De qualquer forma, na Comissão é aprovada, em 20 de novembro de 2013, uma convocação de plebiscito para consultar a população brasileira a respeito da união entre pessoas do mesmo sexo e a suspensão de uma resolução do Conselho Nacional de Justiça (CNJ) que obrigava cartórios a validar casamentos de homossexuais. Conquanto o projeto tenha sido acatado pelos membros da Comissão, a proposta, ao ser levada ao plenário pelos líderes da Câmara dos Deputados, foi rejeitada pela maioria e arquivada. Em 2012, num evento religioso denominado "Congresso de Gideões Missionários da Última

20 Desde o ano 2004 o Governo Federal tem promovido ações para proteção, cidadania e políticas públicas em prol da população LGBT tais como: criação do Programa Brasil Sem Homofobia (2004); realização da I Conferência Nacional de LGBT, com o tema Direitos humanos e políticas públicas: o caminho para garantir a cidadania de LGBTs (2008); lançamento do Plano Nacional de Promoção da Cidadania e Direitos Humanos de LGBTs (2009); publicação do decreto que cria o Programa Nacional de Direitos Humanos (2009); criação da Coordenadoria Nacional de Promoção dos Direitos de LGBT, no âmbito da Secretaria de Direitos Humanos (2010); implantação do Conselho Nacional LGBT (2010) e Relatório sobre Violência Homofóbica no Brasil (anos de 2011 e 2012). Entretanto, Feliciano e os demais membros da CDHM atuam de modo contrário a tudo relacionado à temática. 
Hora", Marco Feliciano em determinado momento de seu sermão apresenta um breve comentário relacionado às pessoas homossexuais e as pautas LGBTs que são levadas por parlamentares à câmara baixa do Congresso Nacional. Ele parte do pressuposto que a heterossexualidade é o padrão estabelecido por Deus para a humanidade e todas as práticas contrárias são próprias de gays, por ele consideradas pecadoras e que herdarão o inferno se não mudarem de atitude. Defender a homossexualidade é o mesmo que ser contra a divindade, segundo ele. Com o intuito de convencer os/as crentes ainda titubeantes quanto ao que havia comentado, declara o seguinte: "A AIDS é uma doença. A AIDS é uma doença que veio desse povo, mas se você falar vai colocar eles numa situação constrangedora, não vai conseguir verba." ${ }^{21}$

Ainda sobre a comunidade LGBT, com o acréscimo do tema do feminismo e aborto, Feliciano é entrevistado em 2012, como parte de uma pesquisa feita por Christina Vital e Paulo Victor Leite Lopes, numa parceria entre a Fundação Heinrich Böll Brasil e o Instituto de Estudos da Religião, titulada "Religião e política: uma análise da atuação de parlamentares evangélicos sobre direitos das mulheres e de LGBTs no Brasil” (2013). Nela, o parlamentar faz críticas à UNICEF e UNESCO, destacando que estas entidades apoiam a "causa gay" por defenderem que a orientação sexual deva ser respeitada desde a infância e que gays tem o direito de adotar crianças. Isso seria uma evidência, segundo ele, de que há um anseio de setores da sociedade em destruir a família tradicional. Esta dissolução, para exemplificar, também teria a participação do movimento feminista conforme as palavras do entrevistado:

As feministas lutam pelo direito delas, o que é legítimo, o que a democracia permite, mas o que vem por trás de tudo isso, de maneira subliminar, é o que me assusta, porque quando você estimula uma mulher ter os mesmos direitos do homem, ela querendo trabalhar, a sua parcela como ser mãe começa a ficar anulada, e pra que ela não seja mãe, só há uma maneira que se conhece: ou ela não se casa, ou mantém um casamento, um relacionamento com uma pessoa do mesmo sexo, e que vão gozar dos prazeres de uma união e não vão ter filhos. Eu vejo de uma maneira sutil atingir a família; quando você estimula as pessoas a liberarem os seus instintos e conviverem com pessoas do mesmo sexo, você destrói a família, cria-se uma sociedade onde só têm homossexuais, e você vê que essa sociedade tende a desaparecer porque ela não gera filhos (CUNHA e LOPES, 2012, p. 155).

${ }_{21}$ Ver: https://www.youtube.com/watch?v=2STDyiAAVsw 
Marco Feliciano, durante a $54^{\text {a }}$ Legislatura, em especial o ano de 2013, concedeu entrevistas, participou de programas jornalísticos e de entretenimento, e em todas essas oportunidades deu declarações que confirmam os posicionamentos conservadores apresentados acima. Quando o órgão de comunicação que o convidava a se pronunciar era ligado a agremiações evangélicas ou católicas, sua argumentação era construída em torno de textos bíblicos e a linguagem adotada era religiosa. E aos outros meios de comunicação não-religiosos, as justificativas para as suas posturas eram relacionadas a questões práticas, como: a homossexualidade não é correta porque impede o crescimento populacional e coopera com a propagação de doenças ou o aborto não pode ser realizado porque é um assassinato e isso fere a Constituição Federal.

\section{Considerações finais}

No ano de 2013, no início do mandato de Feliciano como presidente da CDHM, o influente Pastor da Igreja Assembleia de Deus, Silas Malafaia, em declaração ao Jornal Folha de São Paulo afirma: "Quero agradecer ao movimento gay. Quanto mais tempo perderem com o Feliciano, maior será a bancada evangélica em 2014". ${ }^{22}$ Os dados concernentes às eleições de 2014 não comprovam a previsão de Malafaia, mas um aspecto se concretiza. $\mathrm{Na}$ primeira nomeação do Pastor Marco Feliciano como Deputado Federal (PSCSP), no ano de 2010, ele recebeu 211.855 votos. Já na segunda, em 2014, foram contabilizados 398.087 votos. $^{23}$ Isso significa que ele foi um dos mais bem votados candidatos do Brasil nas duas oportunidades. Ao analisar os eleitos para atuarem entre 2015 e 2018, dos 67 deputados que compunham a Frente Parlamentar Evangélica (FPE), 47 foram reeleitos. Vale lembrar que

22 BARros NETO, N. Feliciano receberá o dobro de votos em 2014, prevê Silas Malafaia. In: Folha de São Paulo, 7 abr. 2013. Ver: <http://www1.folha.uol.com.br/ poder/2013/04/1258589-feliciano-recebera-o-dobro-de-votos-em-2014-preve-silas-malafaia. shtml>.

23 Segundo informações do TSE, em 2014 Feliciano foi o terceiro candidato mais votado do Estado de São Paulo atrás apenas de Celso Russomano (PRB/SP) que obteve 1.512.361 votos e de Tiririca PR/SP que alcançou 1.016 .796 votos. E se comparar com a votação ocorrida em todo o Brasil, Feliciano fica em quarto lugar atrás de Jair Bolsonaro (PP/ RJ) com 464.572 votos (Cf.: http://www.tse.jus.br/eleicoes/estatisticas/eleicoes/eleicoesanteriores/estatisticas-candidaturas-2014/estatisticas-eleitorais-2014-resultados). Já em 2018, concorrendo pela legenda do Podemos, Feliciano foi o $10^{\circ}$ candidato com maior número de votos recebidos no Estado de São Paulo contabilizando 239.784 votos:

http://divulgacandcontas.tse.jus.br/divulga/\#/estados/2018/2022802018/SP/candidatos 
em 2014 foram eleitos 198 deputados $(38,6 \%)$ que nunca exerceram mandato na Câmara dos Deputados, e 315 foram reeleitos. ${ }^{24}$

Confirmando os estudos de Palmeira (1991), Matos, (1994), Carvalho, (2003) Pedde (2004) Machado (2006a, 2006b), Oro (2010) e Burity (2018) sobre a atual "elite parlamentar evangélica direitista e majoritariamente pentecostal”, o Deputado Pastor, no decorrer do seu primeiro mandato, defendeu "bandeiras" marcadas por valores morais cristãos e políticos conservadores. Para tanto, por convicção religiosa e/ou "pragmatismo" para conquistar eleitores, valeu-se de um discurso emotivo, popular, agressivo e excludente. Logo, as polêmicas em que Feliciano se envolveu, acrescidas da exposição dos seus atos nos meios de comunicação e dos eventos pentecostais em que participou como pregador e palestrante, cooperaram com a sua campanha para o exercício do segundo mandato como deputado federal.

À medida que o Deputado se expunha e os programas jornalísticos repercutiam suas atitudes, no ano de 2013, as suas mensagens no Twitter e os diversos vídeos de Marco Feliciano no YouTube passaram a ser replicados, especialmente aqueles que continham as frases homofóbicas e preconceituosas, os sermões nos quais zomba da morte trágica dos integrantes da banda brasileira "Mamonas Assassinas" 25 e do assassinato do cantor John Lennon ${ }^{26}$ que declarou que sua banda, Os Beatles, era mais conhecida que Jesus Cristo, da pregação em que atribui a fama dos cantores Caetano Veloso e Lady Gaga a um suposto pacto demoníaco viabilizado pelo Candomblé. ${ }^{27}$ Juntamente com as entrevistas aos grandes veículos da impressa brasileira e suas ideias apresentadas em frases, sermões e palestras, as manifestações públicas dos opositores de Feliciano auxiliaram na exposição do Deputado. Cabe rememorar os "gritos de guerra" e os "beijaços gays" realizados no parlamento, em templos pentecostais e nas ruas por pessoas contrárias ao deputado. ${ }^{28}$ Lembramos, ainda, a frase "Feliciano não me representa" amplamente divulgada em sites como Facebook e Twitter, bem

${ }^{24}$ Ver: DIAP (www.diap.org.br) e FPE (http://www.fpebrasil.com.br/portal/index.php/ os-deputados).

25 Conforme: https://www.youtube.com/watch?v=M8zkS0BAhAk

26 Ver: https://www.youtube.com/watch?v=8yDtZhQdnB0

27 Segundo: https://www.youtube.com/watch?v=HoB4BOqdp4A

28 Conforme: http://www.ebc.com.br/noticias/brasil/2013/03/beijaco-de-repudio-contrafeliciano-reune-simpatizantes-da-causa-gay-em-sao; E também: https://www.terra.com. $\mathrm{br} /$ noticias/brasil/politica/sp-beijo-entre-mulheres-em-culto-de-feliciano-acaba-em-conf usao,7e9abbdcbf721410VgnVCM4000009bcceb0aRCRD.html 
como a reação dos favoráveis a Feliciano com o compartilhamento do cartaz virtual "Marco Feliciano, Presidente do Brasil".

Em meio às controvérsias mencionadas, Marco Feliciano recebeu apoios importantes nos âmbitos político e religioso, em especial da Frente Parlamentar Evangélica (FPE), com destaque para os Deputados Eduardo Cunha (PMDB-RJ) ${ }^{29}$ e Jair Bolsonaro (PP-RJ) e o Senador Magno Malta (PRES), ${ }^{30}$ e a Convenção Geral das Assembléias de Deus no Brasil (CGADB), formada por vinte e quatro mil pastores assembleianos e agremiações desta instituição, que aprovou, em 9 de abril de 2013, moção em apoio a Marco Feliciano. ${ }^{31}$ Além disso, a partir de maio de 2014, especialmente nos eventos da Assembleia de Deus, Feliciano foi aclamado após ser absolvido em um processo no Supremo Tribunal Federal pela declaração feita no Twitter de que a população negra é amaldiçoada e as pessoas LGBTs são propensas ao ódio e à prática de crimes. ${ }^{32}$

Se fora das dependências da Câmara dos Deputados as ações e palavras de Feliciano contribuíram com a estigmatização e exclusão de negros e gays, no interior do Parlamento, nas reuniões da CDHM, poucos avanços ocorreram no campo dos Direitos Humanos, com destaque para a importante decisão de garantir vagas para pessoas negras em concursos públicos. Cabe retomar que as medidas, os requerimentos e projetos do Deputado Pastor sinalizam uma movimentação parlamentar que aparentemente se iguala ao que fora feito em outras presidências da Comissão. Entretanto, o tratamento que Feliciano e os demais integrantes dão aos temas vão na contramão da ampliação dos direitos. Os objetivos regimentais da CDHM são suplantados

29 Eduardo Cunha, um mês após ter seu mandado cassado pela Câmara dos Deputados por quebra de decoro parlamentar, foi preso em outubro de 2016. Ele foi condenado a 14 anos e 6 meses pelos crimes de corrupção passiva, lavagem de dinheiro e evasão de divisas. Além desta condenação, em junho de 2018, Cunha recebeu uma segunda pena de 24 anos e 10 meses por crimes de corrupção, lavagem de dinheiro e violação de sigilo funcional. Conforme: https://politica.estadao.com.br/noticias/geral,preso-eduardo-cunha-divulgacarta-nas-redes-sociais-e-defende-candidatura-de-lula,70002458368 E, também: http:// www.jmonline.com.br/novo/?noticias, 6,politica, 159852

30 Magno Malta tentou se reeleger em 2018 como Senador pelo Espírito Santo, mas não conseguiu. Ele recebeu 611.284 votos e ficou atrás dos dois candidatos eleitos, a saber, Fabiano Contarato (REDE-ES) que teve 1.117 .036 votos e Marcos do Val (PPS-ES) com 863.359 votos. Ver: http://divulgacandcontas.tse.jus.br/divulga/\#/ estados/2018/2022802018/ES/candidatos

31 Ver: http://www.cpadnews.com.br/integra.php?s=12\&i=15350

32 Matéria do Congresso em Foco: https://congressoemfoco.uol.com.br/especial/noticias/ stf-arquiva-inquerito-contra-marco-feliciano-por-peculato-e-crime-contra-a-honra/ 
em muitos momentos por assuntos religiosos que entram na pauta das discussões. Tais constatações são reforçadas pelas declarações do próprio Deputado em sua página no Twitter, feitas em 13 de março de 2014: "Boa parte da mídia é de militantes que ainda não engoliram o êxito da CDHM em 2013. Não aceitam não terem derrubado a presidência da CDHM. Ainda estão entalados! (rsrsrs) [...] Já disse e repito: estamos tranquilos, esvaziamos a pauta ruim da CDHM e temos na comissão quinze cadeiras; se aparecer algo ruim, obstruiremos!".

Conchavos, conflitos e conluios caracterizaram a presidência do Deputado Pastor Marco Feliciano à frente da CDHM. No espaço da Comissão não houve grandes avanços nos temas que historicamente se desenvolvem ali. É disso que decorre a percepção dos grupos de quilombolas, negros, indígenas e LGBTs que tiveram seus direitos alijados no ano de 2013. De outro lado, a propaganda da defesa de valores conservadores por parte do Deputado, associada às divulgações de polêmicas em sermões e palestras, mostrou-se positiva para a sua popularidade, manutenção e conquista de novos eleitores (BOHN, 2004). De outro lado, sinalizou aos demais políticos da Câmara que evangélicos como Feliciano devem continuar sendo considerados nos jogos internos, nas decisões e nas participações nos espaços de poder. É evidente que a pesquisa sobre o caso Feliciano não se esgotou com este artigo, antes abre novas perspectivas para ampliar o trabalho científico, especialmente se considerar que o Deputado reeleito pela terceira vez em 2018 adotou estratégias eleitorais parecidas com aquelas que o conduziram ao seu segundo mandato, a saber, participação na CDHM, repercussão do seu trabalho na Câmara dos Deputados junto aos eleitores, sermões e palestras religiosas com tom político, e controvérsias com o direito das minorias.

\section{Referências}

ALMEIDA, R. A onda quebrada: evangélicos e conservadorismo. Dossiê Conservadorismo, direitos, moralidades e violência.In: Cadernos Pagu (50), 2017a.

ALMEIDA, R. Os deuses do Parlamento. Novos Estudos. CEBRAP, v. Jun/2017, p. 71 79, 2017b.

AVRITZER, L. Prefácio. In: MARQUES, Ângela (org.). A deliberação pública e suas dimensões sociais, políticas e comunicativas. Belo Horizonte: Autêntica, 2009.

BACCEGA, M. Comunicação e linguagem: discursos e ciência. São Paulo: Moderna, 1998. 
BALANDIER, G. Religião e poder. In: Curso de introdução de Ciência Política. Brasília: UnB, 1982, p. 65-75.

BARRERA RIVERA, P. Religião e política no Peru pós-Fujimori. In: Civitas Revista de Ciências Sociais, v. 06, $\mathrm{n}^{\circ}$ 02, p. 55-75, 2006.

BOBBIO, N.; MATEUCCI, N.; PASQUINO, G. (Coords.). Dicionário de política. Brasília: UnB, 1992. v. 1 e 2.

BORGES, A. Sobre pessoas e variáveis: etnografia de uma crença política. In: MANA 11(1):67-93, 2005

BOSI, A. Dialéticada colonização. São Paulo: Companhia das Letras, 1992.

BRASIL. CONGRESSO. CÂMARA DOS DEPUTADOS. SITE DA COMISSÃO DE DIREITOS HUMNAOS E MINORIAS DA CÂMARA DOS DEPUTADOS. Comissão de Direitos humanos: 10 anos. Brasília: Câmara dos Deputados, Coordenação de Publicações, 2005.

BURITY, J. A onda conservadora na política brasileira traz o fundamentalismo ao poder? In: ALMEIDA, Ronaldo de; TONIOL, Rodrigo (orgs.). Conservadorismos, fascismos e fundamentalismos: análises conjunturais. Campinas: Unicamp, 2018.

BURITY, J. Religião e política na fronteira: desinstitucionalização e deslocamento numa relação historicamente polêmica. In: Revista Eletrônica Rever, São Paulo, nº 4, ano 01, 2001.

BURITY, J. Religião, voto e instituições políticas: notas sobre os evangélicos nas eleições 2002. In: BURITY, J.; MACHADO, M. D. C. (orgs.). Os votos de Deus: evangélicos, política e eleições no Brasil. Recife: Fundação Joaquim Nabuco, Massangana, pp.: 173-213. 2006.

CAMPOS, L. S. De “políticos evangélicos" a "políticos de Cristo": la trayectoria de las acciones y mentalidad política de los evangélicos brasileños en el paso Del siglo XX al siglo XXI. In: Ciencias Sociales y Religión. Asociación de Cientistas Sociales de la Religión del MERCOSUR, Ano 6., n. 7, (2005), Porto Alegre, p. 157-186.

CAMPOS, L. S. Religião, prática política e discurso de evangélicos brasileiros. In: SILVA, Eliane Moura da; BELLOTI, K. K.; CAMPOS, L. S. (orgs.). Religião e sociedade na América Latina. São Bernardo do Campo: Universidade Metodista de São Paulo, 2010, pp. 149-183.

CARVALHO, N. R. E no início eram as bases: geografia política do voto e comportamento legislativo no Brasil. Rio de Janeiro: Revan, 2003.

CASANOVA, J. Public religions in the modern World. Chicago: The University of Chicago Press, 1994.

CDHM. Relatório de atividades - 2011. Brasília: Câmara dos Deputados, Coordenação de Publicações, 2012.

CDHM. Relatório de atividades - 2012. Brasília: Câmara dos Deputados, Coordenação de Publicações, 2013.

CDHM. Relatório de atividades - 2013. Brasília: Câmara dos Deputados, Coordenação de Publicações, 2014. 
CILLA, Karen. C. D. F. \& JARD DA SILVA, Sidney. (2015), "Sindicalismo e políticas públicas: análise do discurso da CUT nos governos FHC, Lula e Dilma”. Idéias - Revista do Instituto de Filosofia e Ciências Humanas da Unicamp, 6: 101-133.

COSTA, E. R. O fundamentalismo evangélico e a política brasileira. In: SOUZA, Sandra Duarte de (Org.). Fundamentalismos religiosos contemporâneos. São Paulo: Fonte Editorial, 2013,p. 73-112.

COSTA, E. R. República Federativa Evangélica: uma análise de gênero sobre a laicidade no Brasil a partir da atuação dos/as parlamentares evangélicos/as no Congresso Nacional no exercício da 54a legislatura. Tese de Doutorado, São Bernardo do Campo, Umesp, 2016.

CUNHA, M. N. O lugar das mídias no processo de construção imaginária do "inimigo" no caso Marco Feliciano. In: Comunicação, mídia e consumo, ESPM, São Paulo, vol. 10, n. 29, set-dez 2013, p. 51-74.

DUARTE, T. A participação da Frente Parlamentar Evangélica no Legislativo Brasileiro: ação política e (In) vocação religiosa. In: Ciencias Sociales y Religión, Porto Alegre, ano 14, n. ${ }^{\circ}$ 17, p. $53-76$, jul/dic 2012.

DUARTE, T. Cultura religiosa e direitos humanos no cotidiano do legislativo brasileiro. In: Cultura y Religion, vol. 7, n. 2, p. 156-170, 2013.

FELICIANO, M. Sem limites - Fly. Orlândia: Tempo de Avivamento, 2015.

FONSECA, A. B. Relações e privilégios: Estado, secularização e diversidade religiosa no Brasil. Rio de Janeiro: Novos Diálogos, 2011.

FRESTON, P. Protestantes e política no Brasil: da Constituinte ao impeachment. Tese de Doutorado, São Paulo, Unicamp, 1993.

FRESTON, P. Religião e Política, sim; Igreja e Estado, não: os evangélicos e a participação política. Viçosa, MG: Ultimato, 2006.

GOUVEIA, E. Entre o templo e a televisão: comunidades eletrônicas de consolo. In: Revista Nures, $\mathrm{n}^{\circ} 01$, ano 01, p. 1-16, 2005.

JARD DA SILVA, S. Bancada sindical, política previdenciária e processo decisório no governo Dilma. In:Revista Brasileira de Ciências Sociais, vol.33, n.98, e339810. Epub July 26, 2018.

JARD DA SILVA, S. Unionism, the Decision-Making Process and Social Security Reform in Brazil. In: Brazilian Political Science Review. 2016, vol. 10, nº2 [29/10/2017].

KUSHNIR, K. Antropologia da política. Rio de Janeiro: Jorge Zahar Editor, 2007.MACHADO, M. D. C. Existe um estilo evangélico de fazer política? In: BIRMAN, Patricia (Org.).Religião e espaço público. São Paulo: Attar, 2003, pp.283-307.

MACHADO, M. D. C.Política e religião: a participação dos evangélicos nas eleições. Rio de Janeiro: FGV, 2006b.

MARIANO, R. A reação dos evangélicos ao novo código civil. In: Civitas: Revista de Ciências Sociais. Vol. 6, $\mathrm{N}^{\mathrm{o}}$ 2, Porto Alegre, EDIPUCRS, 2006.

MARIANO, R. Laicidade à brasileira: Católicos, pentecostais e laicos em disputa na esfera pública. In: Civitas: Revista de Ciências Sociais. Vol. 11, N 2, Porto Alegre, EDIPUCRS, 2011. 
MARIANO, R. Políticos evangélicos à beira de um ataque homofóbico. Trabalho apresentado no XXIX Encontro Anual da ANPOCS. Caxambu, 2005.

MIGUEL, L.; BIROLI, F.; MARIANO, R. O direito ao aborto no debate legislativo brasileiro: a ofensiva conservadora na Câmara dos Deputados. In: Opinião Pública, Campinas, SP, v. 23, n. 1, p. 230-260, ago. 2017.

MIRANDA, Julia. Carisma, sociedade e política: novas linguagens do religioso e do político. Rio de Janeiro, Relume-Dumará, 1999.

MIRANDA, P. Laicidade estatal e liberdade religiosa:decisões políticas influenciadas pelo fundamentalismo homofóbico. In: Jus Navigandi, Teresina, ano 15, n. 2643, set. 2010.

MONTERO, P. Religião, pluralismo e esfera pública no Brasil. In: Novos Estudos - Cebrap, n. 74, 2006.

NOVAES, R. R. Crenças religiosas e convicções políticas: fronteiras e passagens. In: FRIDMAN, Luiz (org.). Política e cultura: século XXI. Rio de Janeiro. RelumeDumará: ALERJ, pp.: 63-97, 2002.

OLIVEIRA, I. M. A. O.A ideologia do branqueamento na sociedade brasileira. Universidade Estadual do Norte do Paraná, Santo Antônio do Paraíso, 2008.

ORLANDI, E. Análise do discurso. Campinas: Pontes, 2003.

ORO, A. P.; MARIANO, R. Eleições 2010: Religião e política no Rio Grande do Sul e no Brasil. In: Debates do NER, v. 1, n. 18, p. 11-38, 2010. Disponível em: <http://seer.ufrgs. br/debatesdoner/article/view/17634/10453>. Acesso em: 20 fev. 2013.

PALMEIRA, M. Política, facção e compromisso: alguns significados do voto. In: Encontro de Ciências Sociais do Nordeste, Salvador, 4/CRH/FINEP/CNPq/ANPOCS, vol.1, p.111130, 1991.

PEDDE, V. A percepção dos fiéis pentecostais quanto ao envolvimento de suas denominações na atividade política. Debates do NER, ano 5 - nº. Porto Alegre, UFRGS, 2004.

PEIRANO, M. De que serve um documento?. In: C. Barreira e M. Palmeira (orgs.), Política no Brasil: visão de antropólogos. Rio de Janeiro: Relume Dumará, p. 25-50.

PIERUCCI, A. Representantes de Deus em Brasília: a bancada evangélica na Constituinte. In: PIERUCCI, Antonio, PRANDI, Reginaldo. A realidade social das religiões no Brasil: religião, sociedade e política. São Paulo: Hucitec, 1996.

PINEZI, A. K. M. Doutrina, experiência e "mudança de vida": a (re)formação das relações familiares e da moralidade entre neopentecostais e protestantes. Trabalho apresentado no XXIX Encontro Anual da ANPOCS. Caxambu, Minas Gerais, 2005.

RIVIÈRE, C. As liturgias políticas. Rio de Janeiro: Imago, 1989.

ROTONDANO, R. Investigando a herança cultural-religiosa brasileira: a dificuldade em instituir um Estado plenamente laico. In: Revista do Direito Público, Londrina, v.8, n.2, p.221-238, maio/ago. 2013.

SADEK, M. T. Discurso política: notas para um debate. In: CHAIA, Vera, RESENDE, PauloEdgar, ALMEIDA, Lucio. Análise do discurso político: abordagens. São Paulo: EDUC, 1999. 
Conchavos, conflitos e conluios: a gestão do ano de 2013201

da CDHM pelo Deputado e Pastor Marco Feliciano

SANTOS, E. W. O PSC e a noção de "Família tradicional" como identidade partidária e religiosa: análise do processo eleitoral de 2014. Dissertação (Mestrado em Ciências da Religião), São Bernardo do Campo, Umesp, 2016.

SANTOS, F.; ALMEIDA, A., "Urgency Petitions and the Informational Problem in Brazilian Chamber of Deputies". In: Journal of Politics in Latin America, 2009, no3, pp. 81-110. 2011a.

SANTOS, F.; ALMEIDA, A. Teoria informacional e a seleção de relatores na Câmara dos Deputados. In: Dados - Revista de Ciências Sociais, 2005, vol.48,no4, pp. 693-735.

SANTOS, F.; ALMEIDA, A. Fundamentos informacionais do presidencialismo de coalizão. Curitiba, Appris, 2011b.

SANTOS, F.; CANELLO, J. Comissões permanentes, estrutura de assessoramento e o problema informacional na Câmara dos Deputados do Brasil. In: Dados - Revista de Ciências Sociais, Rio de Janeiro, vol. 59, no4, 2016, p. 1127-1168.

SYLVESTRE, J. Irmão vota em irmão: os evangélicos, a Constituinte e a Bíblia. Brasília: Pergaminho, 2006.

TADVALD, M. Eleitos de Deus e pelo povo: os evangélicos e as eleições federais de 2010. In: Debates do NER, Porto Alegre, ano 11, n. 18, p. 83-109, 2010.

VITAL, C.; LOPES, P. V. Religião e política no Brasil: uma análise da atuação de parlamentares evangélicos sobre direitos das mulheres e de LGBTs no Brasil. Rio de Janeiro: ISER, 2013.

Submetido em: 13-3-2019

Aceito em: 23-4-2019 